\title{
When the Real Ceases to Exist: Reading the Realm of the Hyperreal in Unni R.'s “Ozhivudivasathe Kali”
}

\author{
Alaka Theres Babu \\ Research Scholar, English \\ St. Joseph's College \\ Devagiri, Kozhikode, Kerala, India \\ alakatheresbabu@gmail.com
}

\begin{abstract}
In the postmodern condition a sign does not indicate an underlying reality but other signs and thus the whole system becomes 'simulation'. Jean Baudrillard the French sociologist, cultural critic and postmodern theorist, in his 1981 work Simulacra and Simulations discusses about what is usually known as 'the loss of the real'. In the contemporary world the distinction between reality and illusion, surface and depth are completely lost. The media mediated world of reality that we perceive today is all a hyperreality. We confront illusions all around us and without which we feel unable to live. What we take in for granted is something that is created for the purpose of to be perceived. All these made up realities become texts as well. In an age of mass production, mass consumption and mass communication the terms 'hyperreality' and 'simulation' signify the virtual or unreal nature of the present day culture. Baudrillard's philosophy centers on these concepts. It is a basic part of human existence to simulate, to imagine scenarios and possible outcomes.
\end{abstract}

Keywords: Postmodernism, Simulation, Simulacra, Real and Hyperreal.

Baudrillard explains his concept of 'simulacra' and 'hyperreal' in context of contemporary culture. According to him contemporary culture deceives human beings by altering the sense of 'hyperreal' and the real. The world of today with its immense capacity to 
produce multitudes of representations cunningly erases the real or the original and exposes the virtual or the hyperreal. Baudrillard explains the nature of the 'hyperreal' in his work Simulations and Simulacra as, "It no longer needs to be rational, because it no longer measures itself against either an ideal or negative instance ... It is a question of substituting the signs of the real for the real" (2).The process of gradual erosion of the original and the situation of the representation is what he termed as 'simulation'. For him the contemporary culture is a 'simulacra' in which endless 'simulations' happen and hence produce 'hyperreals'. Hyperreality thus becomes the metaphor for contemporary world of media culture. Images are continuously produced and reproduced and this perpetual reproduction makes sure the loss of the original. The original thus losses its value of being original and get immersed in the pool of representations. Thus it too turns to nothing more than a representation. . The world is full of images and flooded with information yet the real meaning or the core is missing, "We live in a world where there more and more information, and less and less meaning" (79).The society now is wholly made up of simulations and this replaces reality, if there is one. The simulacrum conceals not the reality or the pure but the void or the absence of a reality.

Thus in the contemporary cultural scenario the only truth is that of 'simulacrum' and it erases the boundary between the real and the 'hyperreal'. Baudrillard in his work Simulations and Simulacra explains three orders of simulations. The first order is of the premodern period where the original or pure is never under the threat of any copies or representations. This is the first order of 'simulation'. An image in this order is inevitably fingers to the original. While looking at the painting of a place it is of no doubt that the place is there somewhere and this is just its image. People then are more close to the original as they perceive the fact that any image signals to the real or the original. The second order comes with industrial revolution where machines took over the part of human beings. The 
phase of industrial revolution is one of mass production. Any image can be produced endlessly. Any image is produced and reproduced endlessly and this became a threat to the original. With the capacity of endless reproduction any image can replace its original yet still nostalgia for the real or the original lingered in society. The reality is even perverted here and the sign is taken as an unfaithful copy.

The third stage of simulation is the masking of the absent reality. Though not a faithful copy, the sign pretends to be one. The images simply claim to be representing something real. The postmodern age nurtured the third order of 'simulacra' in which the real is no longer present. The distinction between the real and the image is erased and people are no longer concerned about any original. Even without seen the painting Mona Lisa people are happy with its copy whether virtual or in paper. They never care about the real or even they are not aware whether there is something as a real or not. Thus the postmodern era becomes "a new era of simulation in which computerization, information processing, and media, cybernetic control systems, and the organization of society according to simulation codes and models replace production as the organizing principle of society" (118). Thus in the 'simulacra' with the three orders of 'simulation' the 'hyperreal' is formed with no obligations to the real or the absence of the real. The 'hyperreal' is in its own capacity. Baudrillard speaks of the hyperreal in terms of simulation, "Simulation is no longer that of a territory, a referential being or a substance. It is the generation by models of a real without origin or reality: a hyperreal" (5). Umberto Eco calls the 'hyperreal', 'authentic fake'. It acts and makes impressions and give effects without referring to anything outside it. There is no referent point upon which it has to act.

Baudrillard further explains on the nature and function of the hyperreal, The real is produced from miniaturized cells, matrices, and memory banks, models of control - and it can be reproduced an indefinite number of times 
from these. It no longer needs to be rational, because it no longer measures itself against either an ideal or negative instance. It is no longer anything but operational. In fact, it is no longer really the real, because no imaginary envelops it anymore. It is a hyperreal, produced from a radiating synthesis of combinatory models in a hyperspace without atmosphere (7).

By analyzing a Malayalam short story titled "Ozhivudivasathe Kali” by Unni R this paper tries to discuss the process of simulation and the formation of hyperreality. The short story is well acclaimed for its brilliantly crafted plot and the treatment of the themes of political corruption and caste prejudices. The story focuses on the activities of five middle aged men on an off day. The central event of the story is the 'play' that these men act out in order to escape from the boring routines. The play they execute and its effects become the plot of the short story. The story proceeds through a thin gap between the real and illusion. As time passes these men get more and more into the play and it seizes to be a pure illusion in the course of time.

“Ozhivudivasathe Kali” (An off Day Game) by Unni Rdeals with an off day activities of four men. Deviating from the usual pattern of an off day where these four men, friends, join together in a lodge room, their usual off day spot, for boozing and casual talks they have decided to play a game. Ashokan, Dharmapalan, Dasan and vinayan are the four friends who came together in the lodge room and planned to play 'kallanumpoliceum' in order to escape from the boring world of realities. No. 70 room of Nanadavanam lodge is their usual off day spot. They first have decided to narrate a story to entertain them but later abandoned the plan for some solid reasons,

They have reached a decision either to narrate a story or to play some games together. With a very small discussion itself they have detected the problem with a story. Anything is fit in a story whether it is a discussion or a 
rumor.Even a doctor's prescription of medicines for a day is a story given it a title. Or what if we start a new story, those characters that turned gods in reinterpretation can intervene at any point of time. And these characters may take us to the world of illusions (61).

As these people were not willing to go with illusions and they want to stick on to realities they abandoned the plan to narrate stories. And thus they decided to play 'KallanumPoliceum'. Dharmapalan dictated the rules of the play to everyone. From there onwards the first stage of simulation starts. Thief, police, king and ministers are the four chits for the play. These names will write in chits and each person will take one without knowing what is written in it. The person who got the chit of police should find out the person who took the chit of the thief. This is the basic rule of the play. As the chits were grabbed by all Ashokan got the chit of police. He declared it right then. Here these men are aware of their real life and they take this play as way out of their daily routine. The reality is out there and they are playing a game. As the play progresses these men get into the play deeply and they are slowly becoming the characters of the play. The second stage of simulation starts there. The play they engaged in becomes a faithless copy of the real or the referent. The real life of them to which this play refer to starts to erode slowly. "The duty of a policeman is to find the thief out"(62). "You will get beaten if you give the wrong answer", Das made Ashokan remember" (62). “Thinking about the punishment Ashokan's felt a pain of his palm”(62) Ashokan then came up with a wrong answer but he escaped from the beating punishment as he asked the others to change the physical punishment to fine and they have agreed to it. Ashokan has mistaken Dharmapalan for thief but he in fact the king. The third stage of simulation starts here. It is Dharmapalan who completely ignores his real life existence and becomes the character in the play. 
"Dharma, please give me some more time". Ashokan said. "I am not Dharman. Dharmapalan corrected in an authoritative tone. "The king". "Please excuse me my lord": said Ashokan. "I have found out the thief"(64).

The play now masks the real life as most of the characters denied their real existence to which the play refers to.

The final stage of simulation starts with the last character Vinayan's complete surrender to the play. "Vinayan bowed down" (65).

The king, minister, police and thief evolved completely out of the play and thus the real fails to exist anymore and the hyperreal evolves. The something to which the play initially referred is now completely disappeared. As the short story reaches its final section Ashokan fails to find out the thief and the play itself reveals the thief as Vinayan. The king, minister and police together killed the thief after the trail. All of them except Vinayan, who has been killed by the others, get out of the lodge room and the room is closed for the next off day. The real ceases to exist anymore and the hyperreal evolves. Baudrillard speaks of the four stages of simulation from the first of a sign representing a basic reality to the last or fourth where the sign holds no relation to any reality at all. Unni R's short story clearly depicts the four stages of simulation and the evolution of the hyperreal. The role play that the characters of the short story execute becomes a system that can be called, according to Baudrillard, a 'simulacrum'. 


\section{Works Consulted}

Brooker, Peter, editor.Modernism/Postmodernism.Longman, 1992.

Foss, Paul, et al, translators.Simulations by Jean Baudrillard, Semiotext(e), 1983.

R. Unni, EntePriyappettaKathakal. DC, 2017.

Woods, Tim. Beginning Postmodernism, Viva Books, 2010. 